basic idea put forward in the article holds, viz. that the stresses induced by the moment at the front of the glacier play a major role in the calving procedure. At present a more correct theory is under elaboration.

Laboratoriet for Hydraulik,

Polyteknisk Lareanstalt, Danmarks Tekniske Hojskole, Oster Voldgade $10 F$, DK-I350 Kobenhain K, Denmark 19 December 1968

Niels ReEH

\title{
REFERENCES
}

Carbonnell, M., and Bauer, A. I968. Exploitation des couvertures photographiques aériennes répétées du front des glaciers vêlant dans Disko Bugt et Umanak Fjord, juin-juillet ig64. I. Nouvelles mesures photogrammétriques de la vitesse superficielle des glaciers du Groenland par M. Carbonnell. II. Accélération de l'écoulement des glaciers groenlandais vers leur front et détermination de leur débit solide par A. Bauer. Meddelelser om Gronland, Bd. I 73 , Nr. 5 .

Sorge, E. 1933. Umiamako- und Rink-Gletscher. Kurzer Bericht über wissenschaftliche Arbeiten, Universal-Dr. Fanck Grönlandexpedition 1932. Berlin, Universal Film-A.G., Presse-Abt.

Steenstrup, K. J. V. 1893. Bidrag til kjendskab til bræerne og bræ-isen i Nord-Grønland. Meddelelser om Grønland, Bd. 4 , Nr. 2.

Sir,

\section{Crystal shape in polar glaciers and the philosophy of ice-fabric diagrams}

In his recent study, Rigsby (1968) found that single crystals in coarse-grained ice from a temperate glacier may branch and rejoin, and may twist about in a very irregular manner in three dimensions. In the process the $c$-axis of the crystal may be bent as much as $10^{\circ}$. In the last paragraph but one, Rigsby suggested that this complex shape of crystals may cast doubt on many fabric diagrams obtained from temperate glacier ice. He observed that it is not known whether crystals of finer-grained ice from polar glaciers are equally complex. Some work that I did in August ${ }_{1967}$, at the Cold Regions Research and Engineering Laboratory, Hanover, New Hampshire, bears on these problems.

Two or more crystals in different parts of a thin section may appear to have nearly identical $c$-axis orientations, and Rigsby's study suggests that these "cells" may be part of the same crystal in three dimensions. This raises the possibility of two types of uncertainty in the preparation and interpretation of fabric diagrams.

First, if the $c$-axes of two cells are nearly parallel, should those two cells be counted as one crystal (I point) or two crystals ( 2 points) in plotting a fabric diagram? If two cells from different crystals are incorrectly thought to be part of the same crystal and thus counted as one point, the fabric will be artificially weakened. This effect might become particularly serious in a fabric with a strong preferred orientation, as many cells might be incorrectly rejected. Furthermore, it is possible that a bent crystal will occur as two cells with different $c$-axis orientations and that both these cells will be counted.

Secondly, crystals may be granulated in regions of high shear strain (Rigsby, 1960, p. 605). A broken crystal would appear as two or more cells in a thin section and if slight rotation of the grains had occurred the $c$-axes of the cells would no longer be parallel. Should such cells be counted as one crystal, or as separate crystals?

Fabric analyses are useful because ice recrystallizes under stress and because crystals assume a preferred orientation during recrystallization such that glide planes are sub-parallel to one another, and to the direction of shear strain. It is necessary to decide whether the critical parameter in this process is the fact that a large number of individual crystals assume a certain orientation, or whether it is more important that in a large percentage of the ice volume, glide planes are sub-parallel to the direction of shear strain. The former case is intuitively more interesting as it treats the mechanics of crystal growth and glacier flow. However, to study this aspect of fabric diagrams it is essential to measure each crystal, including branched or broken crystals, only once. As discussed above this is generally impractical.

Thus in most cases we are forced to the second approach, that of considering the percentage of the volume in which glide planes are sub-parallel to the direction of shear strain. To employ this approach, one should measure the volume of each crystal and weight the points in the fabric diagram proportionally. In general, this is also impractical, but an approximate weighting according to the area of the crystal exposed in a thin section is possible (Kamb, 1959, p. 1900). 


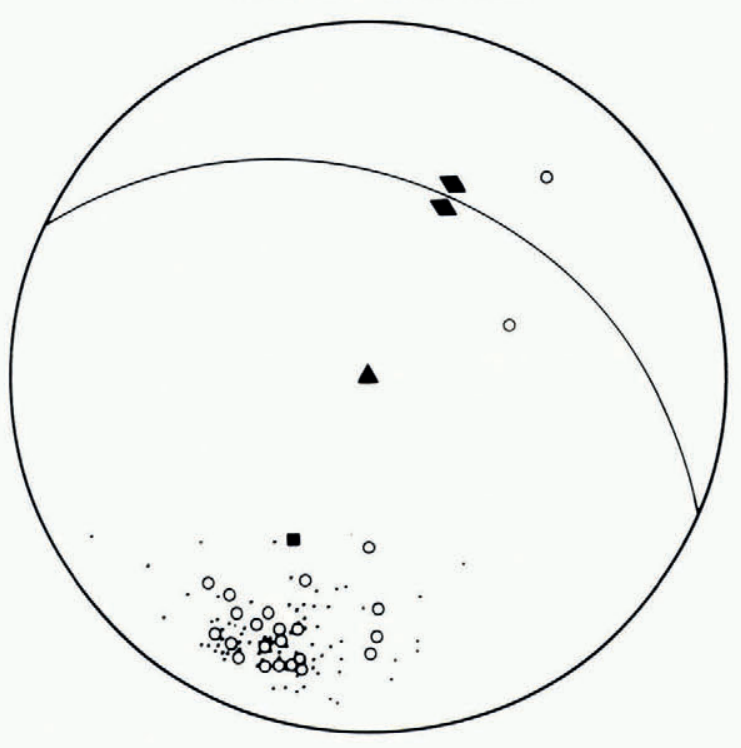

Explanation

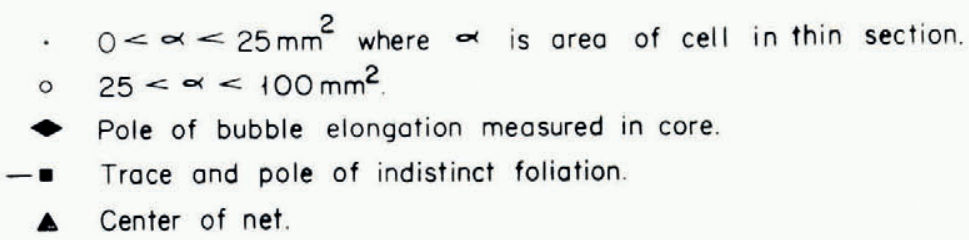

Fig. I. Fabric diagram showing c-axes plotted on the lower hemisphere of an equal-area net.

To study these problems further, serial thin sections were cut at intervals of 3-4 mm from a core collected from beneath $0.5^{2} \mathrm{~m}$ of ablation till above the TUTO ice tunnel near Thule, north-west Greenland, and an attempt was made to trace crystals between sections. The fabric in this core was strong; $34 \%$ of the $c$-axes lay in $\mathrm{I} \%$ of the area of an equal-area net (Fig. I). Relative position and $c$-axis orientation were used to identify crystals in one section that were first selected in an adjacent section. Crystals in the sections averaged $5^{-10} \mathrm{~mm}$ in maximum dimension (Fig. 2), and they were thus more than an order of magnitude smaller than those studied by Rigsby. With cells this size, it was difficult to trace crystals from one section to another, but sections could not be cut at intervals smaller than 3-4 mm with the apparatus at hand. Several of the crystals traced do appear to terminate between sections. Of 20 crystals initially selected, only four could be traced over a distance of $\mathrm{I} \mathrm{cm}$ with any assurance (Table I). This ratio is about what one would expect if the crystals are equant and of the size

Table I. Crystals Traceable between Serial Thin Sections

Of 20 crystals $15-19$ could be traced $3 \mathrm{~mm}$
$8-12$ could be traced $7 \mathrm{~mm}$
$4-7$ could be traced $10 \mathrm{~mm}$

indicated in the thin sections. Thus these crystals do not appear to be long and intertwined as were the larger crystals studied by Rigsby. In a couple of instances a single crystal in one thin section may have split to form two cells in the next section.

These observations suggest two conclusions: first, with cells of this size, it seems unlikely that two or more cells in a thin section would be part of the same crystal. Thus a cell should not be rejected because 


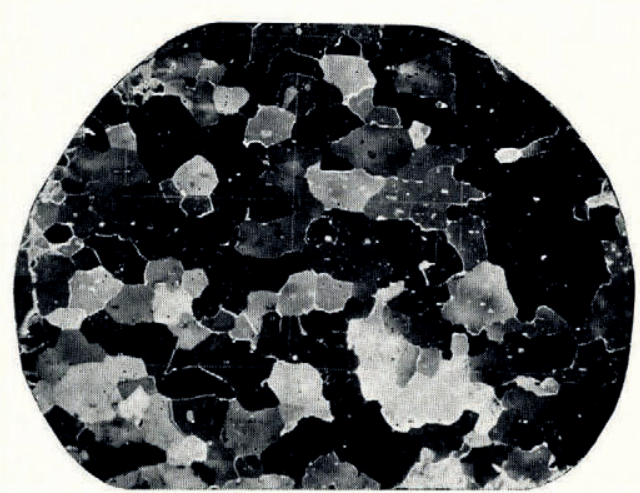

Fig. 2. One of the serial thin sections used in tracing crystals. Crossed polaroids. Grid spacing $20 \mathrm{~mm}$. Section diameter about $70 \mathrm{~mm}$.

its $c$-axis closely parallels that of another. Secondly, because crystals change size when traced through serial sections, it is not generally valid to weight a point in a fabric diagram in proportion to the area of the cell in the thin section; a small cell may be part of a large crystal. Thus the normal fabric diagram in which each cell is given equal weight regardless of size should approximately indicate the percentage of the volume in which glide planes are sub-parallel. This is strictly true only when the crystals are equant in three dimensions.

For these reasons, I submit that previously published fabric diagrams can be accepted at face value. Interpretation of the fabrics is greatly facilitated by knowledge of the texture, as Rigsby (196o, p. 605) realized.

This work was done at the Cold Regions Research and Engineering Laboratory, Hanover, New Hampshire, and was supported by the Graduate School of the University of Minnesota.

\section{Department of Geology and Geophysics, \\ University of Minnesota, Minneapolis, Minnesota 55455 , U.S.A. \\ 4 December 1968}

ROGER LeB. HOOKE

\section{REFERENCES}

Kamb, W. B. 1959. Ice petrofabric observations from Blue Glacier, Washington, in relation to theory and experiment. Journal of Geophysical Research, Vol. 64, No. I I, p. 1891-909.

Rigsby, G. P. 1960. Crystal orientation in glacier and in experimentally deformed ice. Journal of Glaciology, Vol. 3, No. 27, p. 589-6o6.

Rigsby, G. P. 1968. The complexities of the three-dimensional shape of individual crystals in glacier ice. Fournal of Glaciology, Vol. 7, No. 5o, p. 233-51.

SIR, A supraglacial extension of an ice-dammed lake, Tunsbergdalsbreen, Norway: comments on Dr P. $\mathcal{F}$. Howarth's paper

Liestøl (1956) and others (Leopold and others, 1964) have pointed out that the potential energy of water in a drainage system is largely converted into heat. In the case of Brimkjelen, the lake described by Howarth (1968), if we take the volume as $10^{7} \mathrm{~m}^{3}$, the drop from the lake to the snout as $300 \mathrm{~m}$, and the distance as $4 \mathrm{~km}$ (Kick, 1966 ), then the full drainage of the lake could provide enough energy to melt a tunnel $4 \mathrm{~km}$ long and $24 \mathrm{~m}^{2}$ in cross-section. The settling of an irregular ice mass on to an uneven floor would not be likely to cut off all drainage at once. Instead, flow, and thus melting, would be concentrated along a few paths. Even though not all of the available energy would be used for this purpose, melting should be sufficient to keep a tunnel open against slow ice movement. In the absence of very rapid ice movement the tunnel would thus remain open as long as the supply of water lasts, that 